\title{
Analysis of Learning Interests and Student Responses in Online Learning Using E-Learning
}

\author{
Mellyta Uliyandari', Nurlia Latipah ${ }^{2}$, Dewi Handayani3 \\ DOI: $10.35445 /$ alishlah.v13i3.985
}

\begin{abstract}
Article Info
Abstract

Keywords: Interest to learn; Student Response; Online Learning; E-learning

This study aims to analyze interest in learning and student responses in online learning using e-learning media in Universitas Bengkulu. The method used in this research is descriptive qualitative. Data collection was carried out using a questionnaire distributed using google form. Questionnaire analysis was carried out using a mini step application with the Rasch model. The population in this study was 193 science education students with a total sample of 64 people. The results showed that the interest in learning science education students in general chemistry 2 had a conversion value of 78.56, which was in the high category. Meanwhile, the student person towards online learning using elearning media also showed good results, with a conversion value of 60.42 , which was in the good category.
\end{abstract}

\begin{abstract}
Abstrak
Penelitian ini bertujuan untuk menganalisis minat belajar dan respon mahasiswa dalam pembelajaran daring menggunakan media e-learning di salah satu Universitas di Bengkulu. Metode yang digunakan dalam penelitian ini adalah deskriptif kualitatif. Pengumpulan data dilakukan menggunakan angket yang disebarkan dengan menggunakan google form. Analisis angket dilakukan dengan menggunakan aplikasi ministep dengan model rasch. Populasi dalam penelitian ini adalah 193 orang mahaiswa pendidikan IPA dengan jumlah sampel sebannyak 64 orang. Hasil penelitian menunjukkan bahwa minat belajar mahasisa pendidikan IPA pada mata kuliah kimia umum 2 memiliki nilai konversi sebesar 78,56 yang berada pada katagori tinggi. Sedangkan person siswa terhadap pembelajaran daring dengan menggunakan media e-learning juga menunjukkan hasil yang baik, dengan nilai konversi sebesar 60,42 yang berada pada katagori baik.
\end{abstract}

Kata kunci:

Minat Belajar;

Respon Mahasiswa;

Pembelajaran Daring;

E-learning

\section{INTRODUCTION}

The COVID-19 pandemic has had a serious impact on various sectors of life, one of which is the education sector. The coronavirus outbreak has made many countries, especially Indonesia, choose to implement a distance learning system because face-to-face learning is considered to accelerate the spread of the virus. Distance learning is considered an alternative to reduce transmission of the coronavirus, and students can still learn, especially during the pandemic

\footnotetext{
${ }^{1}$ Universitas Bengkulu, Bengkulu, Indonesia

Email: mellytauliyandari@unib.ac.id

2UIN Fatmawati Bengkulu,Bengkulu, Indonesia

Email : nurlialatipah@iainbengkulu.ac.id

3Universitas Bengkulu,Bengkulu,Indonesia

Emai: d.handayani@unib.ac.id
}

Vol.13 (3) December, 2021

Received: August 18, 2021; Received in revised form: October 21, 2021; Accepted: November 2, 2021; Available online: December 31, 2021. This is an open access article under a Creative Commons Attribution-NonCommercial-ShareAlike 4.0 International License. 
(Andriani, 2020). Distance learning is also known as online learning (Belawati, 2019). E-learning is a learning system that utilizes electronic media to assist learning activities. Students do not need to sit in class to listen to any learning material delivered by the teacher directly. The material delivered by the teacher through e-learning learning media can be listened to at any time, wherever the place is, as long as it is connected to the internet network. Thus, e-learning can shorten teaching time and facilitate interaction between students and teachers (Daryanto, 2010).

According to Imaniah \& Siti (2019), the use of e-learning as a learning medium can increase students' absorption of the material being taught, increase active student participation, improve the quality of the material presented, increase the ability to display information with information technology tools and be able to increase interest in learning. Independent students at home. Several studies conducted by several researchers on the online learning process using e-learning media showed positive results. One of them is a study conducted by Sobrok et al. (2019) about student perceptions in the study and the effect of online learning Research conducted by Niki Raga (2019) regarding online learning also showed positive results.

However, in reality, online learning will certainly not be as effective as direct learning. The inability of students and students as well as teachers and lecturers to interact directly in the learning process has caused problems in the learning process. So that online learning can cause polemics where not all students and students respond positively to the implementation of online learning (Purniawan \& Woro, 2020). Technological skills and minimal internet access also create problems in the implementation of online learning (Padli \& Rusdi, 2020). In addition, limitations in internet accessibility, hardware and software, and financing are often obstacles in maximizing online learning resources (Yaumi, 2018). The location of the school and the residences of students and college students are also separate obstacles. Schools located in villages generally have limited internet and technology that supports the learning process so that online learning becomes less than optimal.

The online learning method applied during the COVID-19 pandemic has certainly influenced student learning. The implementation of the learning process for each student can be the same, but the resulting learning outcomes can be different. Several factors that can affect student and student learning outcomes are interest in learning and student and student responses to the learning process. Interest in learning is a condition in which a person has a tendency and a great desire to understand and know something he is learning (Slameto, 2015). According to Darmadi (2017), interest greatly influences learning outcomes. Internal factors and external factors influence interest in learning.

Responses to teachers and lecturers' questions about online learning are included. Getting an accurate answer is critical to helping students' thinking skills for online learning (Arifin, 2020). Research by (Kurniawan \& Woro, 2020) on student responses to online learning shows that 72 per cent of the questionnaire aspects are in good categories, indicating that online learning is being used effectively during the covid 19 pandemic. Students' Online Learning Interests Research by Yulia and Alpha (2021)Students' enthusiasm for an online learning method has been shown to have an impact on their learning outcomes; when students are enthusiastic about a particular learning method, they are more likely to grasp the material being presented. This study's goal is to examine the interest in learning and student responses to online learning in general chemistry classes at Bengkulu University's science education programs. Because no previous study had attempted to analyze both student interest and response in online learning at the same time, this study used e-learning to do so. In order to improve student learning outcomes, it is critical to analyze student interest and response.

\section{METHOD}

This research employs a descriptive qualitative methodology, which focuses on describing, explaining, and answering questions about the problems under investigation by studying as many individuals, groups, or events as possible (Sugiyono, 2016). Students in the FKIP Bengkulu University's Science Education Study Program were surveyed about their interest in learning and 
how they responded to online learning using e-learning media. Even semester of the 2020/2021 academic year. Study participants were all undergraduates at FKIP Bengkulu University who had taken general chemistry courses during their fourth semester.

In order to collect data, a questionnaire was used. Student interest in learning questionnaires and student response questionnaires to online learning using e-learning are distributed to students. In order to distribute questionnaires to students, Google Forms was used. This study used a ministep application to analyse the questionnaire items through the Rasch model approach, more commonly known as the Rasch model. A Likert scale was used to measure students' interest in learning and their responses, but the results were transformed into quantitative data by scoring. Tables 1 and 2 show the categorization of the scoring results for each aspect (Suartama, 2010).

Table 1. Criteria for student interest in learning

\begin{tabular}{cc}
\hline Value Interval & Category \\
\hline $\mathrm{x}>88,2$ & Very high \\
$71,4<\mathrm{x} \leq 88,2$ & High \\
$54,6<\mathrm{x} \leq 71,4$ & Enough \\
$37,8<\mathrm{x} \leq 54,6$ & Low \\
$\mathrm{x} \leq 37,8$ & Very Low \\
\hline
\end{tabular}

Table 2. Student response criteria

\begin{tabular}{cc}
\hline Value Interval & Category \\
\hline $\mathrm{x}>71,34$ & Very high \\
$57,78<\mathrm{x} \leq 71,34$ & High \\
$44,22<\mathrm{x} \leq 57,78$ & Enough \\
$30,66<\mathrm{x} \leq 44,22$ & Low \\
$\mathrm{x} \leq 30,66$ & Very Low \\
\hline
\end{tabular}

\section{FINDINGS AND DISCUSSION}

\section{Analysis of Questionnaire Interests in Learning and Student Responses 1. Interest in learning}

This study used a 21-item learning interest questionnaire focused on happiness, paying attention, interest, and student participation. In the study, it is known that every item of the statement used in the questionnaire distributed to students showed excellent results. Data analysis using the Rasch model shows this to be the case. This questionnaire included statements that were tested for reliability using Fisher's table. Figure 1 shows the outcomes.

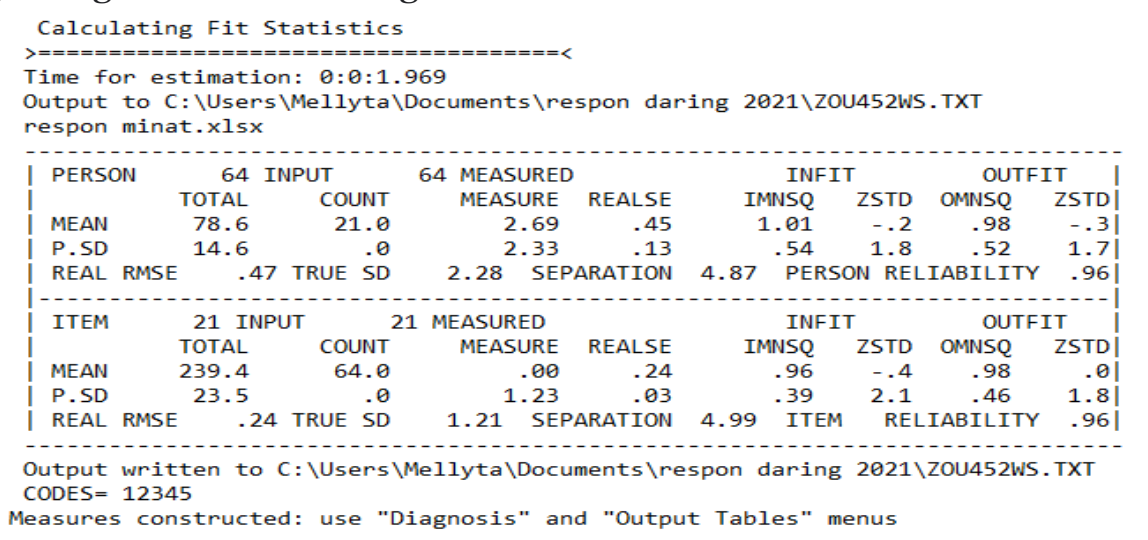

Figure 1. The results of the reliability analysis of the statement of interest in learning

In the above analysis, an item's and a person's reliabilities were found to be 0.96 and 0.96 , respectively. It's safe to say that the data points and respondents in this study are very well aligned. Another good thing to note is the 4.87 to 4.99 rating for the person and item separation, which indicates a wide variety of statements to choose from, allowing for accurate measurement of the items. The difficulty level of the statement items in the learning interest questionnaire was also examined in this study. Figure 2 depicts the findings. 


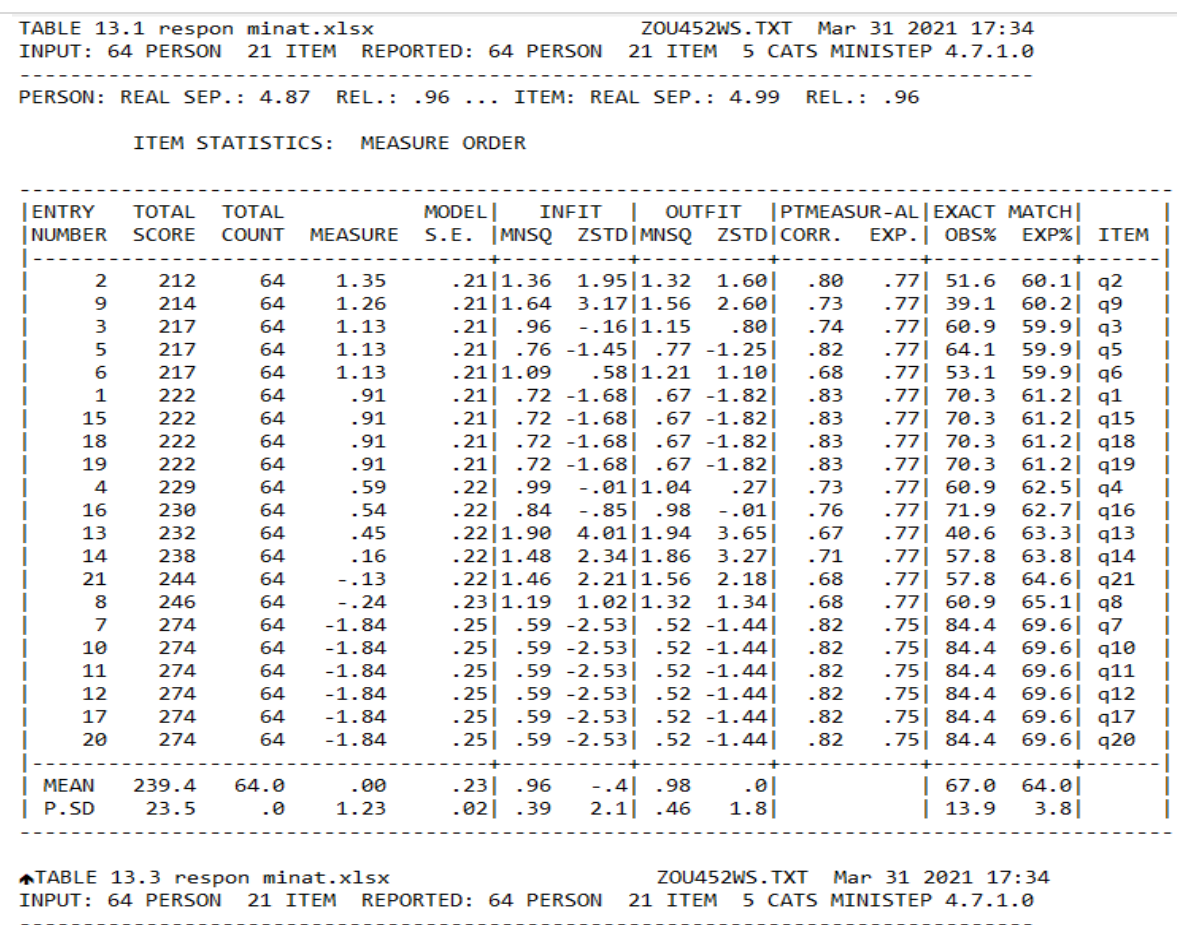

\section{Figure 2. The results of the analysis of the difficulty level of the statement of interest in learning}

Figure 2 shows that, of the 64 people who took the survey, every single one of the statement items was answered by every person. We can also see from this table that statements no. 2 and no. 9 are the most difficult to agree on (q2, q9). Moreover, it can be seen that from the outfit mean square value that it is in the range of 0.5-1.5 (0.59-1.32), Z-standard outfit is in the range of -2.0 ZSTD +2.0 and the point measure correlation is in range of 0.4 Pt Measure corr 0.80, it is stated to be well understood by all respondents, in other words, there are no misunderstandings; (Sumintono \& Wahyu, 2013). The results of the Rasch model analysis also show that each part of the statement works properly, as expected. Figure 3 depicts this.

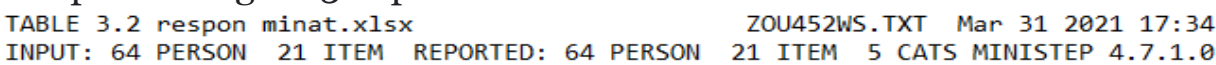

\section{Figure 3. Analysis of the function of the statement of interest in learning}

According to the table above, the rating scale used in the statement is working properly. The observed count is complete, and the category measure rises steadily from -7.24 to 5.96, demonstrating this. The Rasch model method of analysis shows that the learning interest assessment questionnaire has excellent quality. The results of the analysis of respondents and questions show that the majority of respondents agree with all of the questionnaire items and can be used to assess student learning interest in online learning.

\section{Student Response}

Students' reactions to online education were gauged through a response questionnaire consisting of 17 statements. The Rasch model can be used to determine the questionnaire's accuracy 
in gauging student sentiment. The Rasch model was used to analyze the questionnaire items, and the results were excellent. Based on Fisher's table, the reliability of the respondents and the items in this study is in the very good category, at 0.92 and 0.92, indicating that the items and respondents are quite consistent in this analysis. Separation of people and things is also in the good category, with a score of 3.45 and a score of 3.33. As a result, the currently used statement items are diverse and wide-ranging, allowing for accurate measurement. Figure 4 depicts the findings of our investigation.

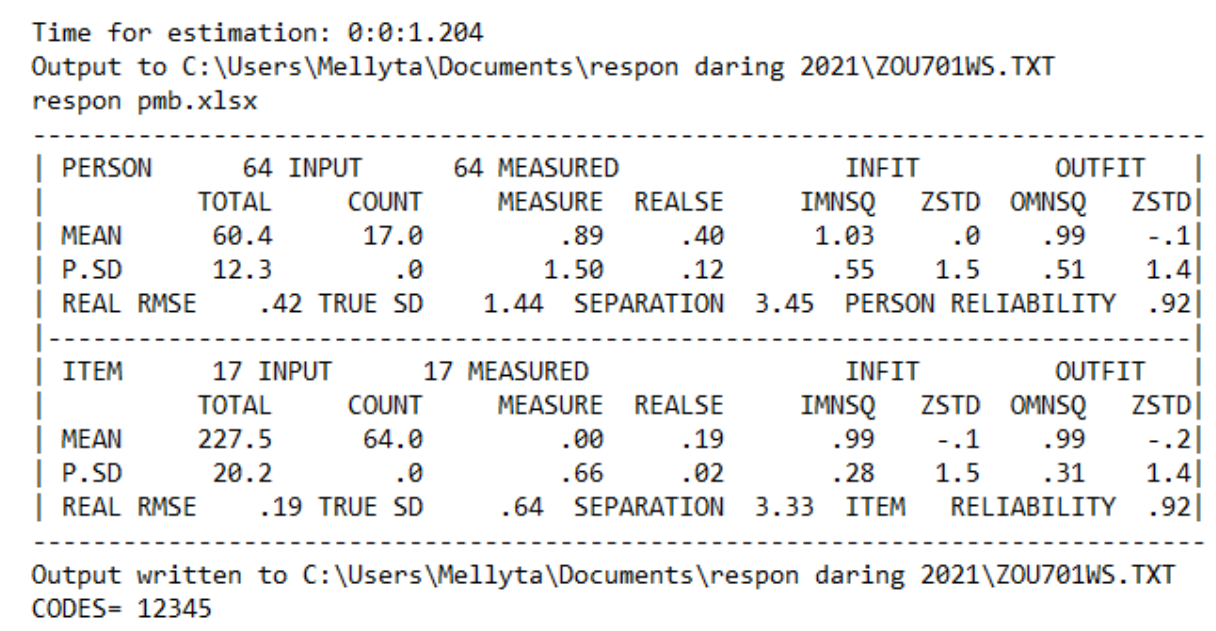

\section{Figure 4. The results of the reliability analysis of student response statements}

Student response questionnaires were also used to examine the difficulty level of statement items. According to the study's findings, all of the people who took part in it answered every question honestly. This is evident from Figure 5, which shows a total count of 64 .

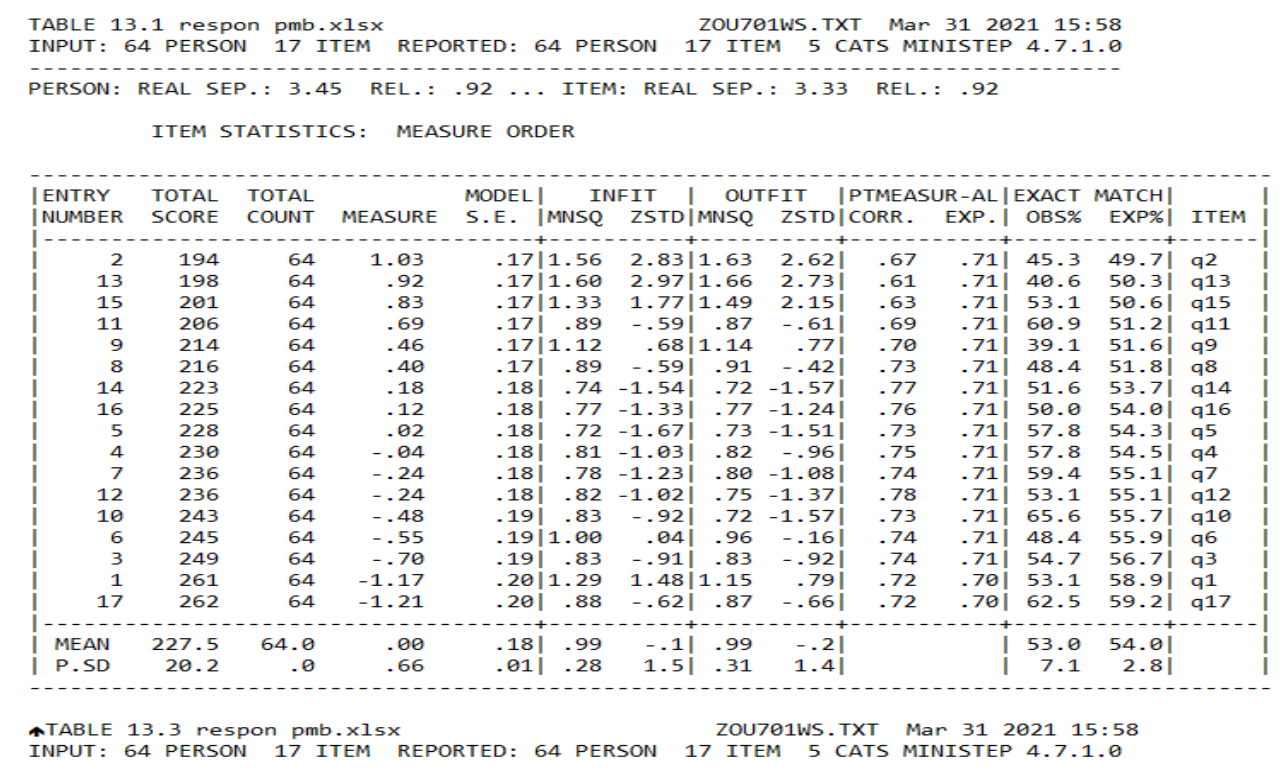

\section{Figure 5. The results of the analysis of the difficulty level of student response statements}

Based on Figure 5, it is known that the item that is the most difficult to agree on is statement item no 2 (q2). Furthermore, from the outfit mean square value, it can be seen that it is in the range of $0.5-1.5$ (1.66-2.62), the Z-standard outfit is in the range of $-2.0<$ ZSTD $<+2.0$ and the point measure correlation with a range of $0.4<$ Pt Measure corr $<0.85$, therefore all statement items are stated to be well understood by all respondents, in other words, there are no misconceptions (Sumintono \& Wahyu, 2013). 
The Rasch model's results for statement item analysis show that each statement item in the survey works well. When you look at Figure 6, you can see that there are no blank spaces in the observed count and the category measure steadily rises from -3.45 to 3.99 .

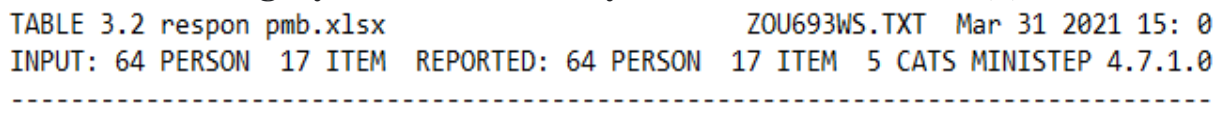

\section{Figure 6. Analysis of the function of the student response statement items}

The Rasch model's results show that the student response assessment questionnaire has excellent quality. As a means of gauging how students respond to online learning. According to survey responses and respondent analysis, the vast majority of survey takers agreed with every single item on the questionnaire.

\section{Analysis of Learning Interests and Student Responses to Online Learning by Using E-learning Media \\ 1. Student's Interest in Learning}

There were positive findings based on research on student interest in Science Education Study Program toward online learning using e-learning media. Student responses to a google form provided the data used to determine this. This questionnaire consists of 21 questions pertaining to aspects of happiness, attention, interest, and student involvement. Table 3 displays the findings of the student interest in learning assessment.

Table 3. Assessment of Student Interest in Learning

\begin{tabular}{cc}
\hline Aspects Rated & Quantity \\
\hline Happy Feelings & 1246 \\
Attention & 1257 \\
Interest & 1259 \\
Student Engagement & 1266 \\
Total & 5028 \\
Conversion Value & 78,56 \\
Category & High \\
\hline
\end{tabular}

Classification of student learning interests based on student learning interest questionnaire data in more detail can be seen in Figure 7. 


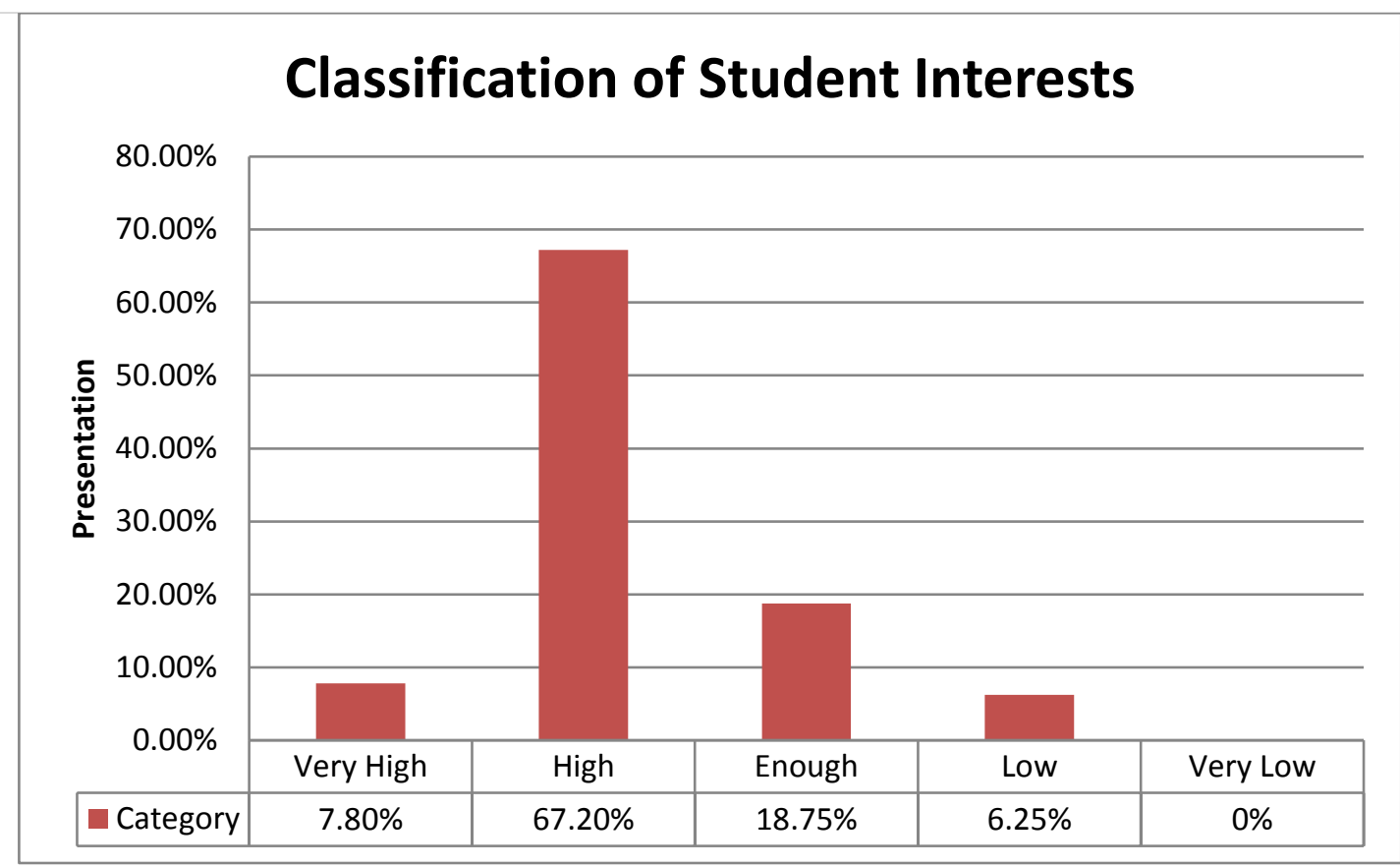

Figure 7. Classification of Student Interest in Online Learning

Based on table 3, it is known that student learning interest in online learning using e-learning media in general chemistry course 2 at the Bengkulu University Science education study program has a conversion value of 78.56, which is in the High category. Based on Figure 7 it is known that there are $7.8 \%$ of students have a very high interest in online learning, $67.20 \%$ of students have a high interest, $18.75 \%$ of students have a fairly high interest, $6.25 \%$ of students have a low interest, and $0 \%$ or no students who have very low interest in learning in online learning.

Interest in learning greatly affects the learning process. Students who have a high interest in learning about a subject will certainly have great attention and curiosity about that course. Interest in learning is also a very strong driver for active student involvement in the learning process. Like, interest, attention, and involvement are all indicators of interest in learning, according to Sudaryono (2012a). Interest can be seen in the enthusiasm of students participating in learning, interest can be measured by someone's response in responding to something, attention can be measured by someone's seriousness in participating in the learning process, and involvement can be measured from the activity and involvement of students participating in the learning process. Internal and external factors play a role in a person's desire to learn. External elements include learning facilities, teacher teaching methods, and feedback systems, while internal elements are those that originate within the student. These include the student's desire and motivation (Simbolon, 2012).

According to the findings of Sudika (2020), there is a relationship between student interest in learning and the use of e-learning and campus environments, with learning motivation serving as a mediating variable. Another study by Hatip and Listiana (2019) found similar results, showing that Edmodo-based e-learning can boost students' interest in learning.

\section{Student Learning Response}

Student responses to online learning with e-learning learning media are in a good category, as the study's findings show This information was gleaned from the results of a survey that collected responses to 17 statements about a variety of topics, including how easy it is to use e-learning media, how effective lecturers are at teaching, whether or not students experience frustration, anxiety, or confusion while using e-learning media, and the learning environment during a pandemic. Students' responses to online learning assessments can be found in table 4 . 
Table 4. Student Response Assessment Results

\begin{tabular}{lc}
\hline \multicolumn{1}{c}{ Rated aspect } & Amount \\
\hline $\begin{array}{l}\text { Ease of using e-learning media in the } \\
\text { learning process during the pandemic }\end{array}$ & 972 \\
\hline Lecturer performance in teaching & 966 \\
\hline $\begin{array}{l}\text { Possible emergence of behavior of } \\
\text { frustration, anxiety, and confusion in } \\
\text { following online lectures with e-learning } \\
\text { media }\end{array}$ & 962 \\
\hline Learning environment during a pandemic & 967 \\
\hline \multicolumn{2}{c}{ Total } \\
Conversion Rate & 3867 \\
Category & 60,42 \\
\end{tabular}

Classification of student responses to online learning using e-learning media can be seen in Figure 8.

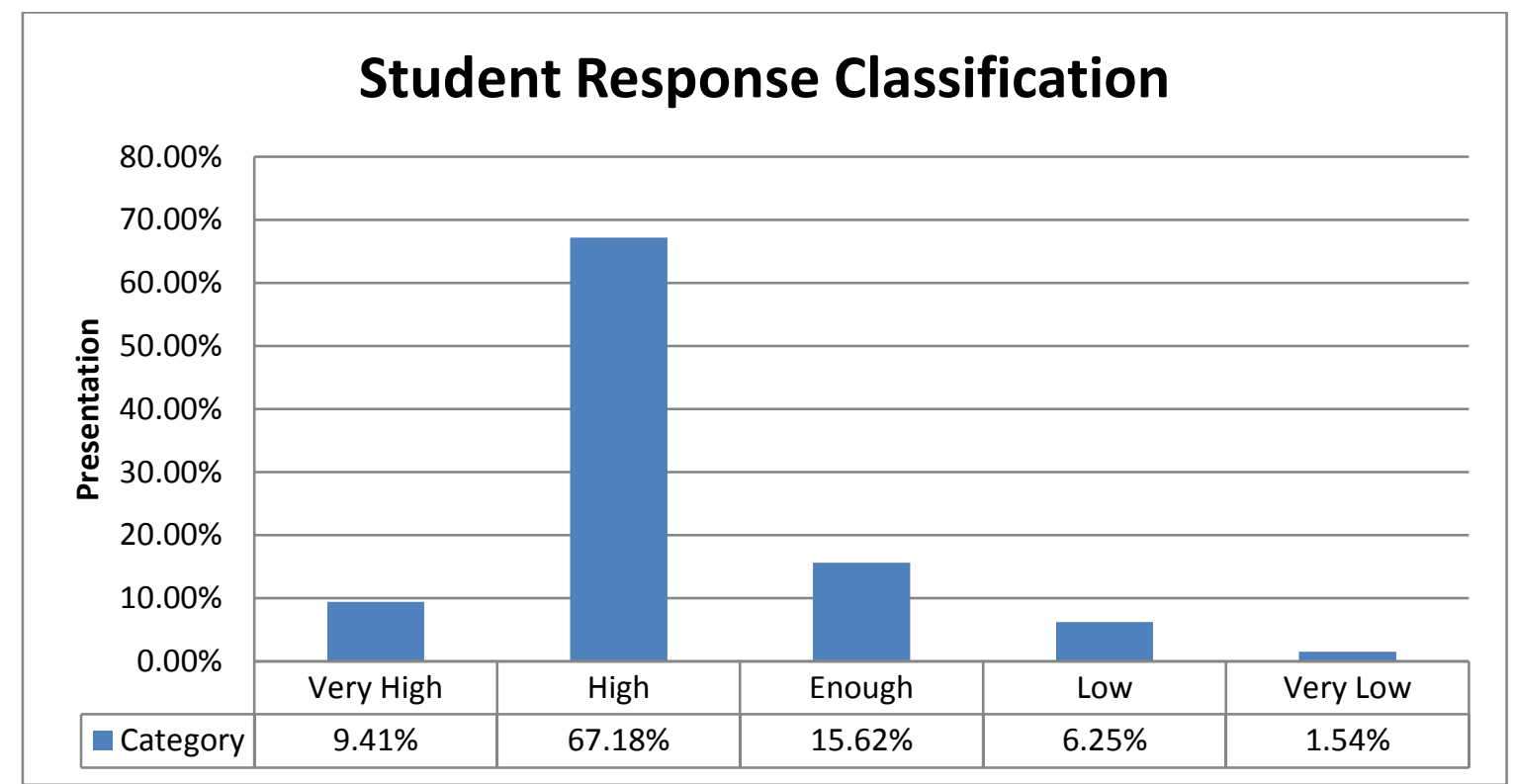

Figure 8. Classification of Student Responses to online learning

Table 4 shows that the response of Bengkulu University science education students to online learning using e-learning has a conversion value on a scale of five of 60.42 and is in a good category. While in Figure 8, it can be seen that there are $9.41 \%$ of students respond very well, $67.18 \%$ respond well, $15.62 \%$ of students have a fairly good response, $6.25 \%$ of students respond poorly, and there are $1,54 \%$ of students who responded not well.

A pandemic of COVID-19 has made it necessary for students to learn online. E-learning is one of Bengkulu University's learning media options. Even though students are unfamiliar with the concept of e-learning, it does not hinder their ability to learn. This is demonstrated by the positive response to e-learning in online education. Lecturers provided learning materials in the form of texts, videos, discussion forums, assignments, and quizzes and exams to get a positive response from students. It is also possible for lecturers to keep tabs on students' progress through e-learning media. For e-learning, the teaching materials developed by the lecturers themselves are more in line with students' needs. Lecturers are responsible for developing their own teaching materials, which must be concise, interesting, and motivating to students (Sutarto, 2020).

The results of this study are in line with research conducted by Setiono (2021), which states that students respond well to activity-based online learning in higher education. Research conducted 
by Tince (2020) also showed consistent results where students gave a very positive response (77.71\%) to online learning and student learning independence during the covid-19 pandemic.

\section{CONCLUSION}

Using e-learning media in Bengkulu University's science education program, students in general chemistry course 2 were interested and responsive to online learning. Interest in general chemistry 2 (conversion value 78.56) is high, as can be deduced from the fact that the student is taking it. In addition, students' responses to online learning were also positive, with a questionnaire data scoring score of 60.42. Students' enthusiasm for learning online and their positive reactions to e-learning media are attributed to the lecturers' use of a variety of teaching methods, such as videos, images, and animations, among others. One of the most appealing aspects of e-learning media is its comprehensiveness, including everything from the presence menu to the chat menu and other features like discussion forums. Students' interest in online learning and their responses to elearning is only examined in this study. In the future, this research could be expanded to include an analysis of student perceptions and student motivation while enrolled in online courses. E-learning media can be widely used to teach students online during a COVID-19 pandemic because the study's findings show that students are interested in learning and respond well to it. This has implications for advancing science in general and education in particular.

\section{REFERENCES}

Arifin,Haris Nursyah. (2020). Respon siswa Terhadap Pembelajaran dalam Jaringan Masa Pandemi Covid-19 di Madrasah Aliyah Al-Amin Tabanan. Widya Balina : Jurnal Ilmu Pendidikan dan Ekonomi 5(9) 1-12.

Andriani, Denny, dkk. (2020). Respon Siswa Terhadap Pembelajaran Dalam Jaringan (Daring) Pada Mata Pelajaran Matematika. Journal ABSIS : Mathematics education Journal. 2(1) 2430. https:// doi :10.32585/absis.v2i1.830

Darmadi. (2017). Pengembangan Model dan Metode Pembelajaran dalam Dinamika Belajar Siswa. Sleman : Penerbit Depublish

Daryanto. (2010). Media Pembelajaran: Perannya Sangat penting Dalam Mencapai Tujuan Pembelajaran. Yogyakarta : Gava Media.

Hatip, H., Listiana, Y. (2019). Minat, kemandirian dan hasil belajar mahasiswa pendidikan matematika dalam e-learning berbasis Edmodo. Jurnal Aksioma, 8(3), 485-496. https://doi.org/10.24127/ajpm.v8i3.226

Imaniah, Kuantum An Nisa \& Siti Khusnul Bariah. Rancangan Pengembangan Instrumen Penilaian Pembelajaran Berbasis Daring. Jurnal PETIK. 5(1) 31-47. https://doi.org/10.31980/jpetik.v5i1.445

Koroh, Tince Dormalin. (2020). Respon Mahasiswa Terhadap Pembelajaran Daring dan Kemandirian Belajar Mahasiswa Selama Pandemi Covid 19,Jurnal Dwyadewata, 3(1) , 5459.

Niki raga tantri. (2018). Kehadiran sosial dalam pembelajaran daring Berdasarkan sudut pandang pembelajar Pendidikan terbuka dan jarak jauh. 19(1) 19-30. https://doi.org/10.33830/ptjj.v19i1.310.2018

Padli, Feri \& Rusdi. (2020). Respon Siswa Dalam Pembelajaran Online Selama Pandemi. Social Landscape Journal. 1(3) 1-7.

Purniawan \& Woro Sumarni. (2020). Analisis Respon Siswa Pada Pembelajaran Daring di Masa Pandemi Covid 19. Analisis Respon Siswa Pada Pembelajaran Daring di Masa Pandemi Covid 19. Prosiding Seminar Nasional Pascasarjana UNNES.

Putri, Yulia Pratami \& Alpha Galih Adirakasiwi.(2021). Analisis Minat Belajar Siswa Kelas X SMA At-Taubah pada Materi SLPTV dengan Metode Pembelajaran Daring. Jurnal Cendikia: Jurnal Pendidikan Matematika, 2934-2940. https://doi.org/10.31004/cendekia.v5i3.987

Setiono. (2021). Analisis Respon Mahasiswa dalam Pembelajaran Online Berbasis Aktifitas di $\begin{array}{lllll}\text { Perguruan Tinggi. } & \text { Jurnal Pendidikan, } & \text { 9(2) }\end{array}$ https://doi.org/10.36232/pendidikan.v9i2.1095 
Simbolon, Naeklan. (2013). Faktor-faktor yang Mempengaruhi Minat Belajar Peserta Didik. Elementary School Journal PGSD FIP Unimed, 1(2) 14-19. https://doi.org/10.24114/esjpgsd.vii2

Slameto. (2015). Belajar dan faktor-faktor yang Mempengaruhinya. Bandung : Rineka Cipta

Sobron, dkk. (2019). Persepsi siswa dalam studi pengaruh daring learning terhadap minat belajar ipa. Universitas veteran bangun nusantara sukoharjo. Jurnal Pendidikan Islam dan Multikulturalisme. 1(2) 30-38. https://doi.org/10.37680/scaffolding.v1i2.117

Suartama. (2010). Pengembangan Multimedia untuk Meningkatkan Kualitas Pembelajaran Pada Mata kuliah Media Pembelajaran. Jurnal Pendidikan dan Pengajaran. 43(3) 253-262.

Sudaryono.(2012).Dasar-Dasar Evaluasi Pembelajaran. Yogyakarta: Graha Ilmu

Sudika,IM, Divayana \& Warpala. (2020). Pengaruh E-Learning dan Lingkungan Kampus Terhadap Minat Belajar Mahasiswa dengan Motivasi Belajar Sebagai Variabel Mediasi. Jurnal Teknologi Pembelajaran Indonesia, 10(10) 87-97. https://doi.org/10.23887/jtpi.v10i2.3354

Sugiyono. (2016). Metode Penelitian Kuantitatif, Kualitatif dan R\&D. Bandung: PT Alfabet.

Sumintono,Bambang \& Wahyu Widhiarso. (2013). Aplikasi Model Rasch untuk Penelitian Ilmuilmu Sosial. Jakarta: Trimkom

Sutarto, S., Sari, D.P. \& Fathurrochman, I., (2020). Teacher strategies in online learning to increase students' interest in learning during COVID-19 pandemi. Jurnal Konseling dan Pendidikan, 8(3) 129-137. https://doi.org/10.29210/147800

Suparno, Paul. (2014). Metode Penelitian Pendidikan IPA. Yogyakarta: Penerbit Universitas Sanata Dharma

Tian Belawati. (2019). Pembelajaran Online. Cet I: Tangerang Selatan : Universitas Terbuka. Cipta. Yaumi, Muhammad. (2018). Media dan Teknologi Pembelajaran. Jakarta : Prenadamedia Grup. 